Dr Dragutin Jovanović, pukovnik, dipl. inž Uprava za školstvo MO, Beograd

\section{MOGUĆNOSTI UNAPREĐENJA PREVOZA SPECIJALNIH TERETA ŽELEZNICOM}

UDC: $656.2: 656.073 .436$

Rezime:

Kvalitet usluge u železničkom saobraćaju i transportu može da se planira. U radu se sagledavaju osnovni parametri kvaliteta usluge i razmatra pitanje upravljanja kvalitetom usluge prevoza specijalnih tereta železnicom, uz primenu dijagrama toka kao jedne od mogućih metoda i tehnika unapređenja kvaliteta. Prevoženje opasnih materija, jedne od grupa iz kategorije specijalnih tereta, nosi niz potencijalnih opasnosti po ugrožavanje životne sredine. Radi bezbednog prevoza železnicom preduzimaju se odgovarajuće mere. Kvalitetna železnička vozila specifičnih konstruktivnih karakteristika, koje odgovaraju fizičko-hemijskim osobinama opasnih materija, uslov su bezbednog prevoza.

Ključne reči: železnica, kvalitet usluge, upravljanje kvalitetom usluge, prevoz, opasne materije, železnička kola.

\title{
POSSIBILITIES OF IMPROVING RAILROAD TRANSPORTATION OF SPECIAL CARGO
}

Summary:

Quality of service in railroad traffic and transportation can be planned. In this paper the basic quality of service parameters are given and question of managing quality of service of railroad special cargos is discussed using the flow diagram as one of the possible methods and techniques for improvement of its quality. Transportation of dangerous materials, ones from the group of special cargos, has a number of potential dangers to the environment. Because of that, certain necessary measures are done to secure safe railroad transportation. Quality railroad vehicles with specific construction characteristics, corresponding to physics and chemical characteristics of the dangerous materials, are condition for safe transportation.

Key words: railroad, quality of service, management of quality of service, transportation, dangerous materials, railroad car.

\section{Uvod}

Specijalnim teretima mogu se smatrati oni koji se primaju za prevoz železnicom pod posebnim uslovima. U grupu specijalnih tereta spadaju predimenzionisani tereti, poznatiji kao naročite pošiljke (NP) i opasne materije (OM).

Prevoz, odnosno transportovanje specijalnih tereta, s obzirom na njihovu priro- du, nosi niz potencijalnih opasnosti po životnu sredinu i učesnike u prevoznom procesu. Od ukupne količine OM u transportu znatan deo prevozi se železnicom.

Železnica pruža usluge prevoza radi zadovoljenja zahteva korisnika koji su usmereni ka usluzi odgovarajućeg kvaliteta. Kvalitet usluge uslovljen je brojnim tehničko-tehnološkim i ekonomskim parametrima. S druge strane, kvalitet uslu- 
ge zavisi i od mnogih subjektivnih ocena i očekivanja korisnika.

U svakodnevnoj praksi pojam kvalitet često se sreće kao univerzalan a, u suštini, obično izražava različitu sadržinu, što zavisi od subjektivne procene pojedinca, odnosno korisnika usluga, o osnovnim karakteristikama, mogućnostima i sposobnostima usluga u zadovoljenju očekivane i izražene potrebe korisnika.

Prevoz specijalnih tereta železnicom proces je visokog rizika i oslanja se na niz kompleksnih i međusobno zavisnih tehničkih, tehnoloških i organizacionih komponenata. Sa aspekta železnice, prevoženje specijalnih tereta uključuje potpunu angažovanost svih raspoloživih resursa infrastrukture i podrazumeva tesnu povezanost sa nadležnim institucijama van železnice. Osnovna pretpostavka bezbednog prevoza OM železnicom je postojanje železničkih vozila odgovarajućih tehničkih karakteristika. U najvećoj meri određuju ih fizičko-hemijske osobine OM.

U ovom radu razmatra se upravljanje kvalitetom usluge prevoza specijalnih tereta, kao deo upravljanja kvalitetom usluge železnice koji je usmeren na ispunjavanje zahteva za kvalitet, uz ukazivanje na moguće metode $i$ tehnike unapređenja kvaliteta usluge.

\section{Usluga prevoza specijalnih tereta železnicom}

Usluga u železničkom saobraćaju i transportu može se definisati kao promena mesta korisnika u putničkom, odnosno tereta u teretnom železničkom saobraćaju. Osnovna karakteristika takve usluge jeste da je ona nematerijalan proizvod i da je proces ,,proizvodnje i potrošnje usluge“" vremenski jedinstven.
Kvalitet usluge može se definisati kao stepen zadovoljenja očekivanja korisnika, a moguće ga je iskazati kao odnos između objektivnih performansi i očekivanja korisnika.

Kvalitet saobraćajno-transportne usluge može se dvojako posmatrati, sa gledišta davaoca (ponuđeni kvalitet) i sa gledišta korisnika (traženi, odnosno očekivani kvalitet).

Kvalitet železničke saobraćajno-transportne usluge može se posmatrati u užem i širem smislu. U širem smislu on obuhvata elemente kvaliteta koji se manifestuju:

- $\mathrm{u}$ trenutku iskazivanja zahteva za prevoznom uslugom;

- $u$ procesu prevoza tereta do krajnjeg korisnika i

- nakon dostavljanja tereta krajnjem korisniku, odnosno naručiocu usluge.

Osnovna karakteristika saobraćajno-transportne usluge svake grane saobraćaja, pa i železnice, definisana je kvalitetom i cenom prevoženja. Nivo vrednosti svakog elementa kvaliteta, kao i kvaliteta usluga u celini, postiže se uz određene troškove. Korisnik od ponuđača - davaoca usluge traži viši nivo kvaliteta, uz što niže troškove.

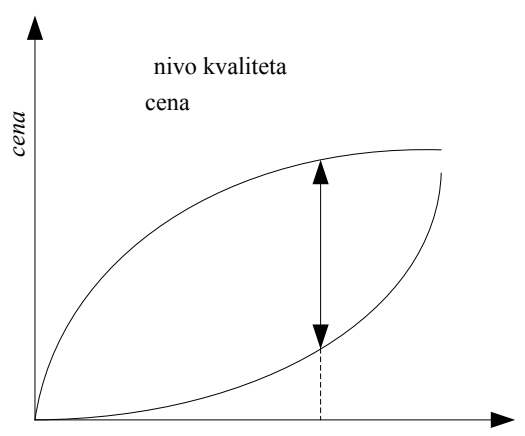

Sl. 1-Odnos cene i kvaliteta usluge 
Kvalitet saobraćajno-transportne usluge, sa jedne strane, objektivno je uslovljen, a istovremeno zavisi i od mnogih subjektivnih ocena i očekivanja korisnika. Pored toga, posmatra se i njen tehničko-tehnološki, kao i ekonomski aspekt. Zahtevi za kvalitet su, u principu, ograničeni cenom. Odnos kvaliteta i cene usluge može se grafički prikazati kao na slici $1[4,5]$.

Odnos prikazan na slici vredi uz pretpostavku da su funkcije troškova (cene) i nivoa kvaliteta progresivne, a nivo kvaliteta u početku raste brže od cene. Optimalni kvalitet se dobija u tački $k$, gde je $d g(k)=d f(c)$. Levo od tačke k žrtvuje se kvalitet, a desno cena brže raste. Pri zahtevu za uslugu određenog nivoa kvaliteta mora se naći optimalni odnos cene i zahteva.

Korisnici zahtevaju usluge sa karakteristikama koje zadovoljavaju njihove potrebe i očekivanja, i u suštini predstavljaju zahteve korisnika. Prihvatljivost usluge utvrđuje na kraju sam korisnik. Potrebe i očekivanja korisnika se menjaju vremenom sa promenom uslova konkurencije i tehničko-tehnološkog napretka, što od davaoca usluge traži da je stalno poboljšavaju.

Prevoz, odnosno transportovanje OM, s obzirom na njihovu prirodu, nosi sa sobom niz potencijalnih opasnosti. Problem zaštite od dejstava OM podrazumeva tri osnovne grupe aktivnosti:

- izučavanje karakteristika OM radi sagledavanja mogućnosti i načina njihovog štetnog delovanja,

- definisanje mera zaštite radi eliminisanja mogućnosti nastanka akcidenata $\mathrm{i}$ smanjenja eventualnih posledica,

- preduzimanje mera za bezbednije prevoženje.

Po poreklu nastanka OM su prirodni ili sintetički proizvodi ili proizvod hemij- skih transformacija. Imaju svoju upotrebnu vrednost, a deo poseduje i određena svojstva koja u izvesnoj meri predstavljaju opasnost po čoveka i njegovu životnu sredinu.

Za praktičnu primenu odgovarajućih mera zaštite, zbog velikog broja materija koje poseduju neko od opasnih svojstava, postoje određena pravila klasifikacije $u$ odnosu na koje je moguće definisati grupe OM sa sličnim osobinama. Štetno dejstvo OM na čoveka, biljni i životinjski svet, nežive materije i predmete, može se manifestovati direktno i indirektno.

Za konkretnije sagledavanje potencijalne opasnosti pri radu sa nekom OM, potrebno je analizirati i njene fizičko-hemijske osobine. U principu, za klasifikaciju OM važne su sledeće osobine: agregatno stanje, viskozitet, gustina, napon pare, temperatura ključanja, temperatura topljenja, temperatura zapaljivosti, temperatura samozapaljenja, granice eksplozivnih smeša, reaktivnost u odnosu na druge materije, itd.

$\mathrm{U}$ procesima reprodukcije $\mathrm{OM}$ se pojavljuju na više mesta: u proizvodnji, pretovaru, transportu (prevozu), skladištenju i potrošnji. U svakoj od ovih faza postoje određene specifičnosti, kako u pogledu izloženosti žive i nežive materije dejstvu OM, tako i u pogledu stepena potencijalne opasnosti, što nameće potrebu za primenom različitih mera zaštite.

U procesima pretovara, transporta i skladištenja postoji viši stepen potencijalne opasnosti od dejstva OM nego u procesima proizvodnje i potrošnje. $U$ toku pretovara, transporta i skladištenja veoma je izražen rizik od nastanka neželjenih efekata, a stepen ugroženosti ljudi i životne sredine vrlo je visok. 
$\mathrm{U}$ toku transportovanja $\mathrm{OM}$, zbog potencijalnih opasnosti, mora se posvetiti posebna pažnja. Sva lica koja učestvuju u transportnom procesu kao i druga lica koja se mogu naći u zoni potencijalnog dejstva OM u toku njihovog transportovanja, izložena su mogućim pojavama neželjenih posledica. One mogu nastati usled akcidenata $\mathrm{u}$ toku transportovanja, i njima su izloženi atmosfera, vodotokovi i ostali elementi okoline, i to na relativno većim udaljenostima od mesta nastanka akcidenta.

Zbog velikog značaja transporta OM pojavili su se i međunarodni propisi koji su se razvili u okviru pojedinih vidova transporta, a i preporuke kojima se pokušalo postizanje uniformnosti granskih propisa. Oni su poslužili kao osnov za donošenje nacionalnih propisa. Međunarodni propis u železničkom saobraćaju je Pravilnik o međunarodnom železničkom prevozu opasnih materija (Reglament concernat le transport international ferroviaire des marchandises dangeureuses - RID) [1].

$\mathrm{Za}$ definisanje preventivnih mera zaštite od neželjenog dejstva OM potrebno je, na početku, utvrditi šta to utiče na vrstu i intenzitet opasnosti $\mathrm{u}$ toku transporta. Polazni osnov su fizičko-hemijske karakteristike OM i njihovog pojavnog oblika i tehnologija transportnog procesa.

Primena svih preventivnih mera sprovodi se radi sprečavanja pojave akcidenata pri radu sa OM ili smanjenja posledica štetnog dejstva u slučaju nastanka akcidenta.

Shodno svojim tehničko-tehnološkim karakteristikama, železnica ima mogućnost pružanja usluge prevoza spe- cijalnih tereta (opasnih materija, predimenzionisanih tereta i sl.).

Predimenzionisani tereti odnose se na njihovu masu i zapreminu. To su svi oni tereti čiji utovar, prevoz, istovar ili pretovar, s obzirom na železničke kapacitete, izaziva naročite poteškoće, i koji se mogu primati na prevoz samo pod posebnim tehničkim i eksploatacionim uslovima. Takvi tereti na železnici su poznati pod domaćim nazivom ,naročite pošiljke“ (NP).

Organizacija prevoženja takvih tereta železnicom predstavlja složeni proces koji se sastoji od mnoštva aktivnosti, a radi stvaranja jasnije slike ovog procesa, i preduzimanja mera za njihovo unapređenje-poboljšanje, potrebno je iznaći i primeniti adekvatnu metodu.

\section{Upravljanje kvalitetom železničke usluge}

Upravljanje (odnosno menadžment) kvalitetom železničke saobraćajno-transportne, odnosno železničke usluge, može se posmatrati kao kompleksan proces usmeren na efikasno izvršavanje zadataka prevoza radi postizanja unapred utvrđenih zajedničkih ciljeva. Ono, kao proces, obuhvata više različitih potprocesa, i to: planiranje, organizovanje, kontrolu, itd.

U standardu ISO 9001 specificirani su zahtevi za sistem upravljanja (menadžment) kvalitetom. Taj standard sam po sebi ne utvrđuje zahteve za usluge. Njih mogu izraziti korisnici, a mogu se specificirati propisom [9].

Kvalitet železničke usluge može se planirati. To je deo upravljanja kvalitetom usluge koji je usmeren na uspostavljanje 


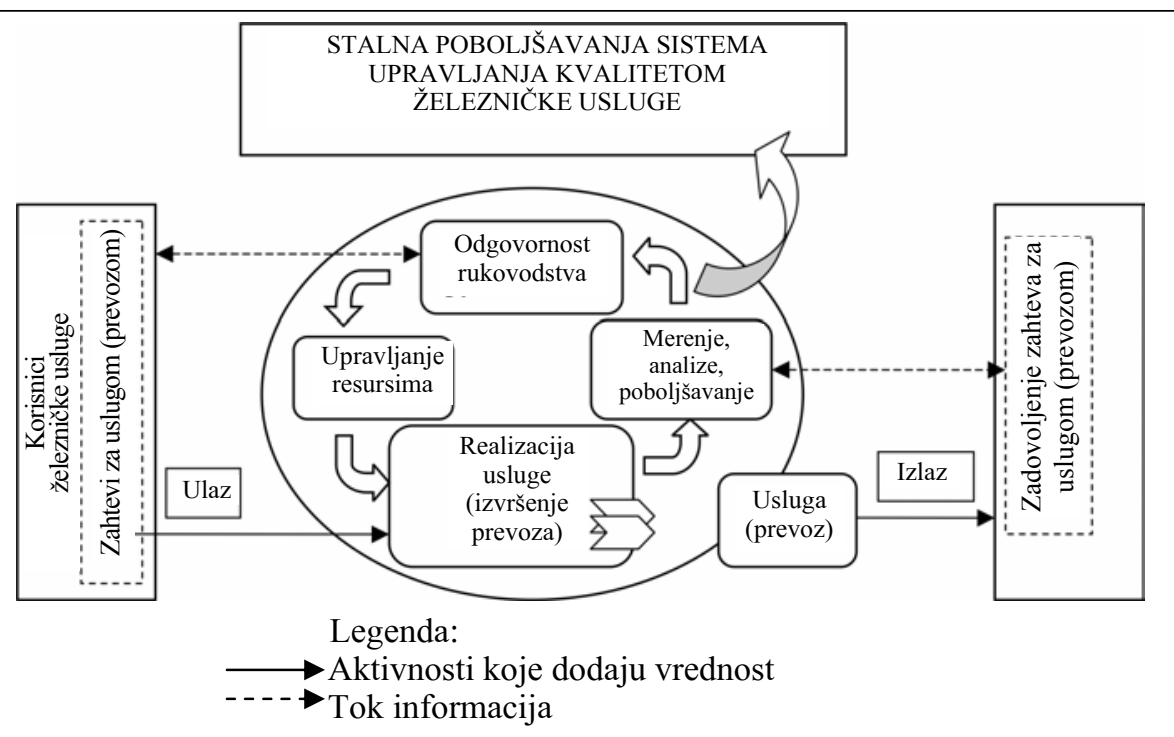

Sl. 2 - Model sistema upravljanja kvalitetom železničke usluge zasnovanog na procesima

ciljeva njenog kvaliteta i na utvrđivanje neophodnih operativnih procesa i potrebnih odgovarajućih resursa (železničkih kola, lokomotiva, infrastrukture i sl.) za ispunjavanje ciljeva kvaliteta usluge.

Upravljanje kvalitetom železničke usluge, kao deo menadžmenta, usmeren je na ispunjavanje zahteva kvaliteta (slika 2).

Uz to neprekidno se vrši poboljšavanje kvaliteta usluge, kao deo menadžmenta, koji je usmeren ka povećanju sposobnosti železničke organizacije da ispunjava zahteve korisnika.

Poboljšanje kvaliteta obuhvata mere koje se preduzimaju za unapređenje osobina i karakteristika usluga i povećanja efektivnosti i efikasnosti procesa pružanja usluge. Proces poboljšanja treba da obuhvati [7]:

- definisanje, analizu i merenje postojeće situacije,
- uspostavljanje ciljeva poboljšanja,

- traganje za mogućim rešenjima,

- analizu identifikovanih rešenja,

- primenu izabranih rešenja,

- verifikaciju, analizu i merenje realizovanih aktivnosti,

- formalizovanje procesnih izmena.

\section{Primena dijagrama toka za unapredenje kvaliteta usluge prevoza specijalnih tereta}

Metode i tehnike unapređenja kvaliteta železničke usluge do sada nisu dovoljno obrađivane.

Jedna od njih je i dijagram toka. To je, u suštini, tehnika grafičkog prikazivanja odvijanja određenog procesa. Cilj grafičkog prikazivanja može biti snimanje postojećeg stanja procesa i dobijanje 
jasne slike njegovog stvarnog odvijanja radi osnove za detaljnu analizu procesa $\mathrm{i}$ eventualno unapređenje. Pored toga, dijagram toka može se koristiti kao podsetnik, odnosno kratko radno uputstvo za izvođenje procesa.

U prikazivanju dijagrama toka koriste se standardni simboli algoritamskog programiranja. Primena dijagrama toka preporučuje se pri izradi dokumenata sistema kvaliteta saglasno zahtevima standarda serije ISO 9000. Svaki proces koji se sastoji od više aktivnosti, a koji treba da se propiše dokumentom sistema kvaliteta, trebalo bi, uz tekstualni opis, da se opiše i dijagramom toka.

Bezbednost prevoza OM je element kvaliteta železničke usluge, a njegova organizacija i izvršenje predstavlja složeni proces sastavljen od većeg broja aktivnosti, koje su vrlo često međusobno uslovljene.

O vanrednom događaju pri prevozu OM železnicom mora se odmah izvestiti nadležni organ i intervenisati na odgovarajući način. Da bi se stvorila jasnija slika tog procesa i preduzele mere za njegovo unapređenje, odnosno poboljšanje, potrebno je iznaći i primeniti adekvatnu metodu. Usled vanrednog događaja na železnici (tehnička neispravnost, dotrajalost materijala, nepažnja i propusti radnika ili prekomerno jaki udari pri prevozu) može doći do rasturanja, istakanja ili razlivanja OM. Pri tome su neposredno ugroženi radnici koji učestvuju u prevoženju OM, a zavisno od njihove vrste i količine i okolni prostor. Izveštavanje o vanrednom događaju i intervenisanje je potproces organizovanja i upravljanja prevozom. Ono kao funkcija ima zadatak iznalaženja adekvatnih postupaka za pravovremeno izveštavanje i preduzimanje interventnih mera za otklanjanje ili ublažavanje mogućih štetnih posledica.

Redosled aktivnosti u procesu izveštavanja i intervenisanja pri vanrednom događaju u prevozu OM železnicom, prikazan na slici 3, jeste sledeći [6]:

1. Izveštavanje o vanrednom događaju pri prevozu OM. Ovu aktivnost obavlja radnik železnice. Ukoliko se vanredni događaj dogodio u stanici, na najbrži mogući način izveštava se otpravnik vozova te stanice ili dispečer telekomande, a ako se dogodio na otvorenoj pruzi izveštava se otpravnik vozova najbliže železničke stanice. Pored usmenog obaveštenja radnik železnice podnosi i pismeni izveštaj svom rukovodiocu, koji mora da sadrži podatke o: mestu i vrsti vanrednog događaja, ljudskim žrtvama, povređenim licima i privremeno preduzetim merama za obezbeđenje mesta gde se desio.

2. Izveštavanje šefa stanice. Ovu aktivnost obavlja otpravnik vozova koga je prethodno obavestio radnik železnice. Izveštaj se dostavlja odmah, prvo usmeno, a zatim i pismeno.

3. Izveštavanje ostalih službi i organa. Po pravilu, to obavlja šef stanice na čijem se području desio vanredni događaj. O njemu izveštava: dispečera područne otpravne službe, koji obaveštava dispečersku službu ŽTP-a, najbliže profesionalno vatrogasno društvo, najbližu stanicu policije, tehničko-kolsku službu, vuču vozova, ZOP i ETD i savetnika za bezbednost prevoza OM.

4. Izveštavanje o vanrednom događaju većih razmera. Ukoliko je isticanje $\mathrm{OM}$ većeg intenziteta, tako da je skupljanje $u$ intervencijske posude nemoguće, pa dolazi 


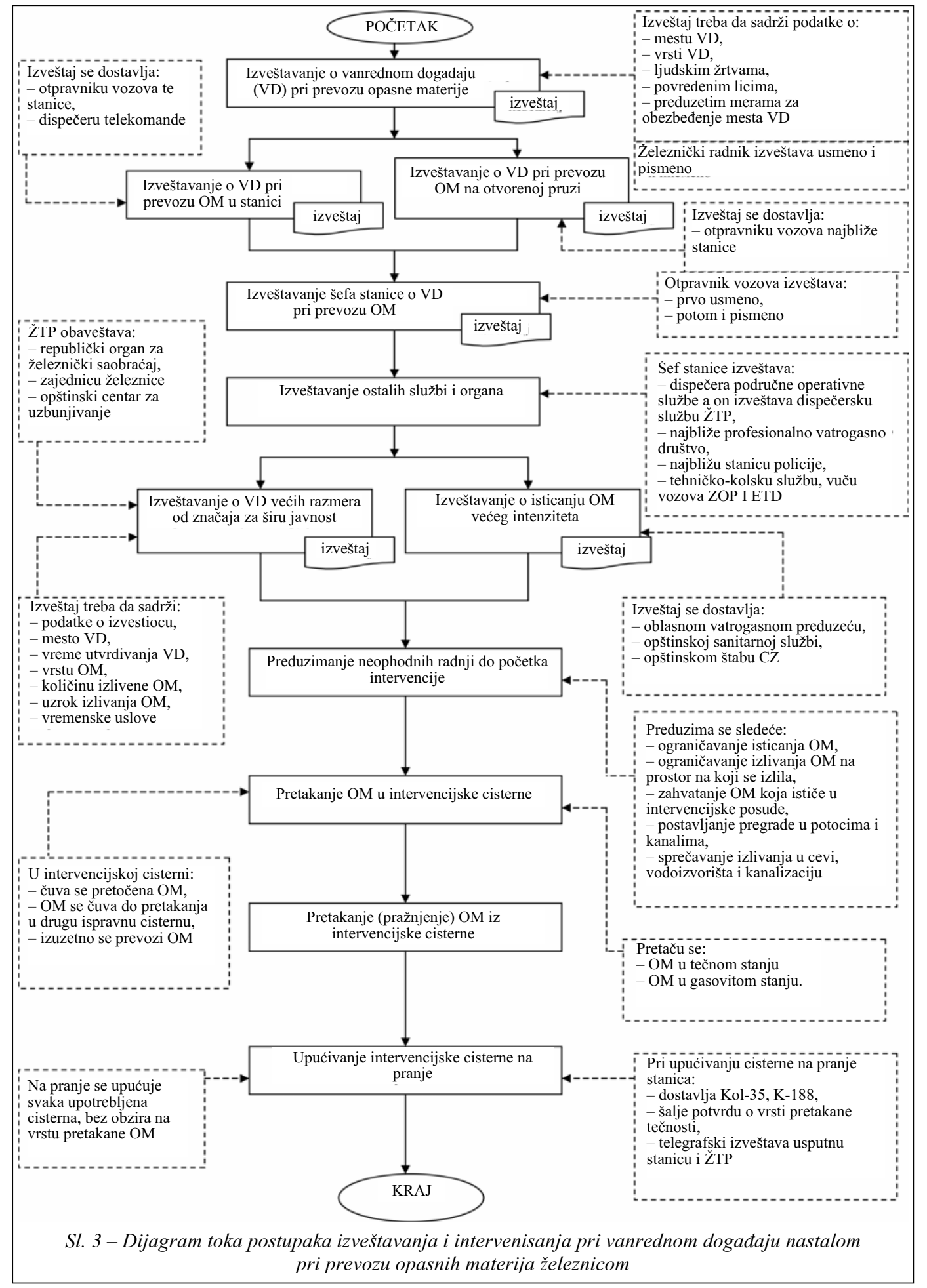


do razlivanja po okolini, obaveštava se: oblasno vodoprivredno preduzeće, opštinska sanitarna služba i opštinski štab civilne zaštite. U slučaju vanrednog događaja pri prevozu OM većih razmera, koji ima značaja za širu populaciju, ŽTP mora, po prijemu obaveštenja od šefa stanice, obavestiti: republički organ za železnički saobraćaj, zajednicu železnice i odgovarajući opštinski centar za obaveštavanje. Zvanični izveštaj o vanrednom događaju pri prevozu OM nadležnim institucijama mora da sadrži: podatke o izvestiocu, tačno mesto njegovog nastanka, vreme njegovog utvrđivanja, vrstu $\mathrm{OM}$, količinu eventualno izlivene tečnosti, uzrok isticanja i vremenske uslove.

5. Preduzimanje neophodnih radnji do početka intervencije. Ova aktivnost sadrži sledeće aktivnosti: ograničavanje isticanja $\mathrm{OM}$, ograničavanje izlivene OM na prostor na koji se izlila, zahvatanje OM koja ističe $\mathrm{u}$ intervencijske posude, postavljanje pregrada u potocima i kanalima i sprečavanje izlivanja u cevi vodoizvorišta i kanalizaciju.

6. Pretakanje OM u intervencijske cisterne. Obavlja se ukoliko su oštećene posude u kojima se prevozi OM u tečnom ili gasovitom stanju. Pretočena OM se u intervencijskoj cisterni čuva do ponovnog pretakanja u drugu odgovarajuću ispravnu cisternu. U izuzetnim slučajevima se, uz saglasnost ŽTP-a, može izvršiti prevoz OM u intervencijskoj cisterni.

7. Pražnjenje OM iz intervencijske cisterne. Obavlja se po dolasku druge ispravne cisterne, koja odgovara određenim zahtevima, ili po izvršenom prevozu, ukoliko je OM prevezena intervencijskom cisternom.

8. Upućivanje intervencijske cisterne na pranje. Obavlja se nakon svake upotrebe intervencijske cisterne, bez obzira na vrstu istočene OM. Pre njenog upućivanja na pranje, stanica koja je upućuje mora uz nju po- slati odgovarajuću dokumentaciju (Kol-35, K-188 i potvrdu o vrsti istakane OM). Pored toga, stanica istovremeno izveštava telegrafskim putem stanicu u koju upućuje cisternu na pranje, kao i ŽTP. Upućivanjem intervencijske cisterne na pranje završava se proces izveštavanja $i$ intervenisanja pri vanrednom događaju nastalom u prevozu OM železnicom.

\section{Konstrukcioni zahtevi za železnička vozila za prevoz opasnih materija}

U cisternama, kao specifičnim sudovima, prevoze se tečne, gasovite, praškaste i zrnaste OM. Cisterne se sastoje od jednog ili više sudova sa opremom i postolja. Pored toga, one poseduju sopstvenu opremu: za kretanje, ogibljenje, vučni i odbojni uređaj, kočnicu, uređaje za punjenje, pražnjenje, provetravanje, osiguranje, zagrevanje, toplotnu zaštitu, spoljašnje ili unutrašnje elemente za ukrućivanje, elemente za pričvršćivanje i zaštitu suda, određene merne instrumente i ostalo.

Pritisak u sudu, koji se pojavljuje u zavisnosti od stepena opasnosti pojava je o kojoj se mora voditi računa pri određivanju debljine suda. Pri njegovom punjenju ili pražnjenju kod pojedinih vrsta OM pojavljuje se određeni pritisak. Imajući u vidu vrstu OM cisterne se izrađuju od pogodnih materijala koji moraju biti otporni na lom i prskanje i neosetljivi na naponsku koroziju u određenom temperaturnom režimu. Kod zavarenih sudova mora se voditi računa da šavovi budu izrađeni prema odgovarajućim tehničkim propisima, kako bi se obezbedila potpuna sigurnost.

$\mathrm{S}$ obzirom na to da pojedine $\mathrm{OM} \mathrm{u}$ dodiru sa zidom cisterne reaguju agresivno tako što stvaraju opasne produkte ili 
osetno slabe materijal, mora se izabrati odgovarajući materijal za cisternu ili adekvatna unutrašnja zaštitna prevlaka. Zaštitna prevlaka mora biti izrađena tako da obezbedi zaptivnost bez obzira na moguće deformacije pri prevozu. Kod prevoza pojedinih vrsta OM može doći do progresivnog smanjenja debljine zidova, što se mora uzeti u obzir pri određivanju njihove debljine. Minimalna debljina zida cilindričnog dela suda mora da odgovara debljini koja se dobija prema izrazu [1]:

$e=\frac{P_{p_{a}} \cdot D}{2 \cdot \sigma \cdot \lambda}[\mathrm{mm}] \quad e=\frac{P_{b a r} \cdot D}{20 \cdot \sigma \cdot \lambda}[\mathrm{mm}]$

gde je:

$P$ - proračunski pritisak $\mathrm{P}_{\mathrm{p}_{\mathrm{a}}}(\mathrm{MPa})$ odn. $\mathrm{P}_{\text {bar }}$ (bar),

$D$ - unutrašnji prečnik suda (mm),

$\lambda$ - koeficijent kvaliteta zavarenog šava, $\sigma$ - dozvoljeno naprezanje $\left(\mathrm{N} / \mathrm{mm}^{2}\right)$.

Uređaji za opsluživanje i oprema suda, odnosno sud kao celina, mora biti izrađen tako da obezbedi prevoz bez gubljenja sadržaja OM. Pored toga, železnička kola - cisterne moraju, pored naprezanja pri normalnom radu, obezbediti otpornost i na druga moguća naprezanja.

Oprema cisterni mora biti izrađena i postavljena tako da obezbedi potpunu sigurnost kao i sam sud. To znači da mora da obezbedi:

- nepropustljivost, kako u normalnim uslovima tako i pri prevrtanju kola;

- pravilno postavljanje zatvarača;

- osiguranje od neželjenog otvaranja zatvarača i sistema za punjenje i pražnjenje;
- otvor odgovarajuće veličine radi unutrašnjeg pregleda;

- adekvatan otvor za čišćenje cisterne.

Zavisno od vrste OM, cisterne moraju imati posebnu zaštitu. Pri izboru materijala za sud - cisternu i njegovu debljinu treba imati u vidu ekstremne temperature pri prevozu, odnosno punjenju ili pražnjenju.

Pored navedenih opštih konstrukcionih zahteva železnička kola - cisterne moraju da zadovolje i druge brojne posebne uslove. Definišu ih sledeće vrste OM: sabijeni gasovi pretvoreni u tečnost ili gasovi rastvoreni pod pritiskom; zapaljive tečne materije; zapaljive čvrste materije; organski peroksidi; otrovne materije; radioaktivne materije i nagrizajuće materije.

Organizovanje prevoza naročitih pošiljki (NP) železnicom je procesna funkcija kojom se pronalaze postupci, organizacijska struktura i ostvaruje priprema za izvršenje planiranog prevoza. Ono predstavlja jedan od glavnih potprocesa upravljanja prevozom NP. Organizovanje i planiranje prevoza NP, kao dva potprocesa, ujedno su i osnovne faze procesa upravljanja prevozom. U okviru planiranja određuju se ciljevi prevoza i zadaci koji se time žele postići, a u okviru organizovanja logička struktura svih aktivnosti i resursa, koja treba da omogući realizaciju planiranog prevoza. Početak procesa organizovanja prevoza, NP železnicom je zahtev za prevoz, a na kraju procesa je realizacija samog prevoza.

Redosled aktivnosti u procesu organizovanja prevoza NP železnicom, prikazan na slici 4, jeste sledeći [4]:

1. Podnošenje zahteva za prevoz NP. Ovu aktivnost obavlja korisnik usluge, a izlazni dokument je prijava za prevoz. 


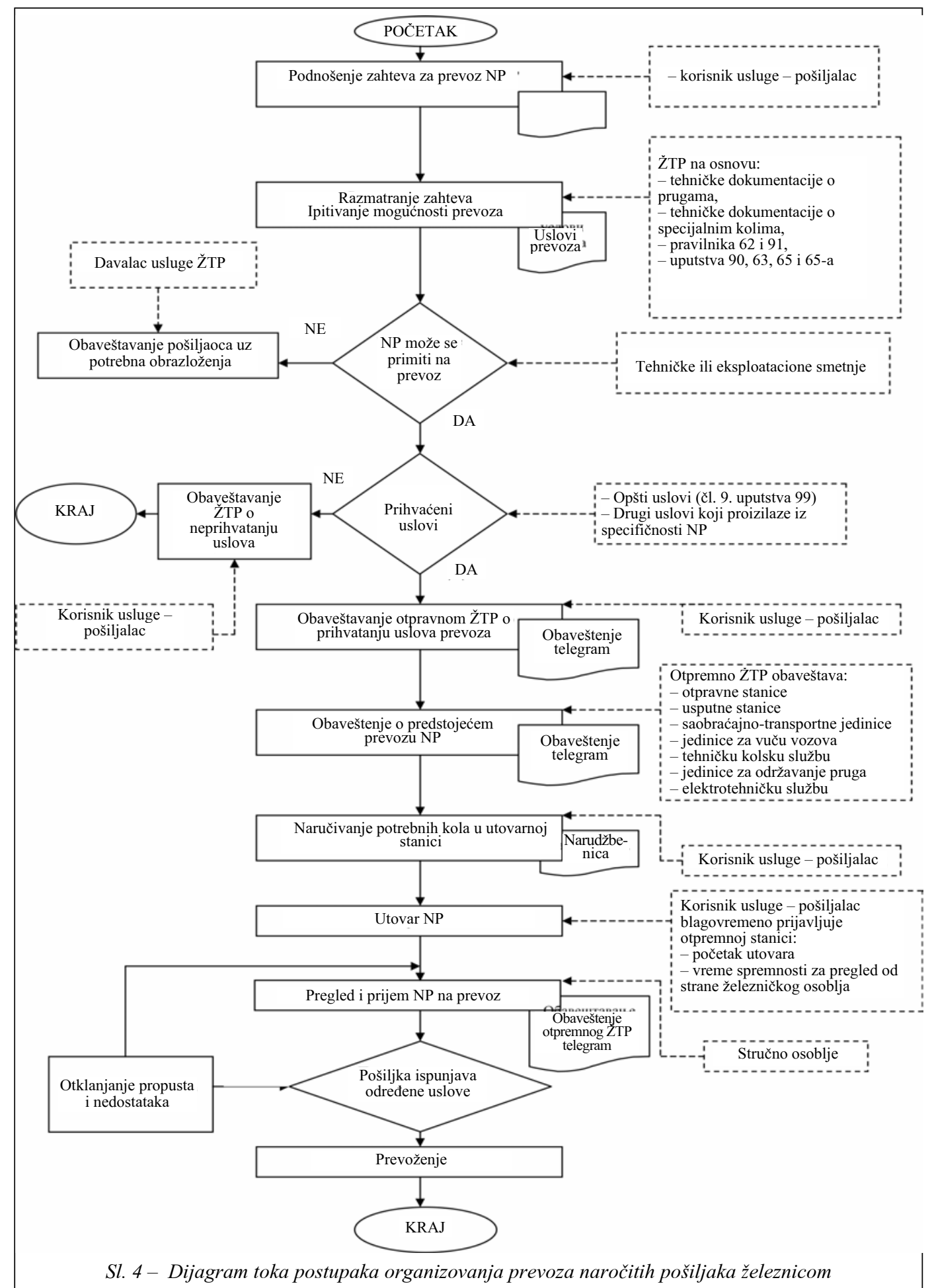


2. Razmatranje zahteva - ispitivanje mogućnosti prevoza. Ovu aktivnost obavljaju stručni železnički organi sagledavajući tehničku dokumentaciju konkretne pruge i specijalnih kola koja ce biti upotrebljena za najavljeni prevoz. Uz to se koriste podaci, odnosno uputstva i instrukcije iz Pravilnika 62 i 91 i Uputstva 90, 63, 65 i 65-a. Izlazni dokument su uslovi prevoza. Ukoliko se zahtev zbog tehničkih ili eksploatacionih smetnji ne može ispuniti, odnosno NP ne može primiti na prevoz, podnosilac zahteva se obaveštava o tome uz potrebna obrazloženja. Ako se NP može primiti na prevoz pod definisanim uslovima koje korisnik usluge ne može prihvatiti, o tome obaveštava ŽTP (železnicu) i tada se proces završava, a ako korisnik usluge prihvati uslove prevoza tada sledi naredna aktivnost.

3. Obaveštenje otpravnog ŽTP o prihvatanju uslova prevoza. Ovu aktivnost obavlja korisnik usluge, a izlazni dokument predstavlja obaveštenje - telegram.

4. Obaveštenje o predstojećem prevozu NP. Ovu aktivnost obavlja otpravno ŽTP, obaveštavajući o predstojećem prevozu: otpravnu stanicu, sve usputne stanice, saobraćajno-transportne jedinice, jedinice za vuču vozova, tehničku kolsku službu, jedinice za održavanje pruga i elektrotehničku službu. Izlazni dokument je obaveštenje - telegram.

5. Poručivanje potrebnih kola u utovarnoj stanici. Aktivnost obavlja korisnik usluge, a izlazni dokument je narudžbenica.

6. Utovar NP. Aktivnost obavlja korisnik usluge, koji blagovremeno prijavljuje otpremnoj stanici početak utovara i vreme kada je stručno železničko osoblje spremno da izvrši pregled.
7. Pregled i prijem NP na prevoz. Aktivnost obavlja stručno osoblje ŽTP-a, a izlazni dokument je obaveštenje otpremnog ŽTP - telegram. Ukoliko se pri pregledu utvrdi da NP ne ispunjava određene uslove, tada se otklanjaju propusti i nedostaci, nakon čega se ponovo obavlja pregled. Ako NP ispunjava određene uslove prelazi se na sledeću aktivnost.

8. Prevoženje. Ovu aktivnost obavlja železnica, a njenim završetkom proces organizovanja prevoženja NP železnicom se završava.

\section{Održavanje železničkih vozila za prevoz predimenzionisanih tereta}

Najveći broj teških borbenih vozila, inžinjerijskih mašina i raznih borbenih sistema pripada grupi predimenzionisanih tereta. Takvi tereti se, uglavnom, prevoze specijalnim plato-kolima. Kod pojedinačnih i po obimu manjih prevoženja ne pojavljuju se veće poteškoće po pitanju obezbeđenja dovoljnog broja plato-kola. Problemi mogu nastati kada se ukaže potreba za masovnijim prevoženjima navedenih sredstava, jer je broj ispravnih plato-kola ograničen. Visok stepen njihove imobilizacije, pored starosti, uslovljen je sledećim razlozima:

- nedostatak rezervnih delova,

- nedostatak sredstava za nabavku novih, remont i održavanje postojećih kola,

- neopremljenost postrojenja za remont kola,

- izostanak agregatne zamene sklopova, 
- neadekvatna postrojenja i uređaji tekućeg održavanja i sl.

Svesni činjenice da u narednom periodu neće doći do radikalnijih pomaka $u$ uvećanju kolskog parka plato-kola, pitanju njihove pravilne eksploatacije i kvalitetnijeg održavanja mora se posvetiti što veća pažnja.

Oznake plato-kola serija Smmps-tz imaju sledeće značenje:

$\mathrm{S}$ - plato-kola specijalnog tipa,

$\mathrm{mm}$ - dužina kola ispod $15 \mathrm{~m}$,

$\mathrm{p}$ - kola bez visokih stranica,

s - kola sposobna za brzine do 100 $\mathrm{km} / \mathrm{h}$,

t - kola za prevoz teških pošiljki,

z - kola sa ručnom (pritvrdnom) kočnicom.

Šematski prikaz kola ove serije prikazan je na slici 5, a tehničke karakteristike u tabeli 1 .

Tabela 1

Tehničke karakteristike plato-kola serije Smmps-tz (472)

\begin{tabular}{|c|c|c|c|c|}
\hline $\begin{array}{l}\text { Redni } \\
\text { broi }\end{array}$ & \multicolumn{2}{|l|}{ Naziv } & $\begin{array}{l}\text { Jed. } \\
\text { mere }\end{array}$ & Količina \\
\hline 1. & \multicolumn{2}{|l|}{ Broj osovina } & kom. & 4 \\
\hline 2. & \multicolumn{2}{|c|}{ Razmak stožera obrtnih postolja } & $\mathrm{m}$ & 7,20 \\
\hline 3. & \multicolumn{2}{|c|}{ Razmak krajnjih osovina } & $\mathrm{m}$ & 9,00 \\
\hline 4. & \multicolumn{2}{|c|}{ Dužina preko odbojnika } & $\mathrm{m}$ & 12,24 \\
\hline 5. & \multicolumn{2}{|c|}{ Korisna dužina poda } & $\mathrm{m}$ & 10,80 \\
\hline 6. & \multicolumn{2}{|c|}{ Korisna širina poda } & $\mathrm{m}$ & 3,15 \\
\hline 7. & \multicolumn{2}{|c|}{ Korisna površina poda } & $\mathrm{m}^{2}$ & 34,00 \\
\hline 8. & \multicolumn{2}{|c|}{ Sopstvena masa } & $\mathrm{t}$ & $20,3021,10$ \\
\hline \multirow{7}{*}{9.} & \multicolumn{2}{|c|}{ Granica tovarenja } & & \\
\hline & - obični & A & $\mathrm{t}$ & 38,00 \\
\hline & \multirow{2}{*}{ teretni režim } & B & $\mathrm{t}$ & 40,50 \\
\hline & & $\mathrm{C}$ & $\mathrm{t}$ & 59,50 \\
\hline & \multirow{2}{*}{ - režim "S" } & A & $\mathrm{t}$ & 38,00 \\
\hline & & $\mathrm{BC}$ & $\mathrm{t}$ & 40,50 \\
\hline & \multicolumn{2}{|c|}{ - režim "S S" ABC } & $\mathrm{t}$ & - \\
\hline 10. & \multicolumn{2}{|c|}{ Režim razmene } & & $\mathrm{NE}$ \\
\hline
\end{tabular}

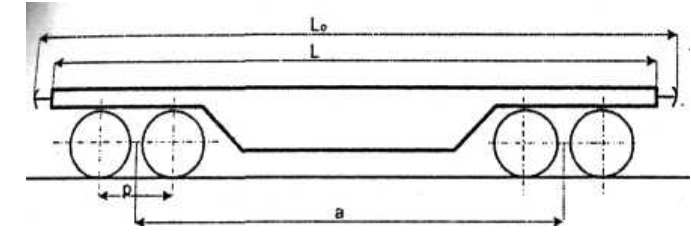

Sl. 5 - Šematski prikaz plato-kola serije Smmps-tz (472)

Vanredne opravke mogu biti malog obima (tekuće opravke) i većeg obima. U vanredno održavanje spada i pranje, čišćenje i dezinfekcija kola, a obavlja se prema ukazanoj potrebi.

Zbog specijalne namene i zahtevane pouzdanosti kola serije Smmps u eksploataciji, njihovom održavanju mora se posvetiti nužna pažnja, posebno pri izvođenju radova u velikoj redovnoj opravci (VO). Opis radova kod velike opravke ovih kola, po konstrukcionim grupama, sa potrebnim norma-časovima, prikazan je u tabeli 2 .

Kao i sva ostala teretna kola uvršćena u vozni park železnice, plato-kola serije $\mathrm{S}$ podležu redovnom i vanrednom održavanju. Redovno održavanje deli se na stalni nadzor, vanredne preglede i redovne opravke. Stalni nadzor plato-kola u eksploataciji obavlja se pri pregledu kola, $i$ to: pre utovara, posle utovara, posle istovara i pre dodavanja kola vozu. Pored navedenih vrsta pregleda pojedinačnih kola obavlja se i pregled kola u vozovima, $\mathrm{i}$ to: pri otpravljanju (odlasku), pri prolazu i pri prispeću (dolasku) voza.

Kola serije Smmps imaju samo veli$\mathrm{ku}$ (VO) redovnu opravku sa rokom od 60 meseci (5 godina), a nemaju kontrolne preglede.

Nakon izvršene velike opravke kola potrebno je izvršiti izradu, pored ostalog, i sledeće remontno-tehničke dokumentacije: mernu listu donjeg postolja kola, mernu listu nosećih lisnatih gibnjeva, mernu listu prstenastih opruga vlačne spreme, mernu listu kvačila, dijagram rada rasporednika kočnice. 
Tabela 2

Opis radova kod VO plato-kola serije Smmps-tz

\begin{tabular}{|c|c|c|}
\hline $\begin{array}{r}\text { Redni } \\
\text { broj }\end{array}$ & Naziv radova & $\begin{array}{l}\text { Potrebno } \\
\text { norma- } \\
\text {-časova }\end{array}$ \\
\hline 1. & 2 & 3. \\
\hline $\mathbf{A}$ & Donji postroj i obrtno postolje & \multirow{5}{*}{38} \\
\hline 1. & $\begin{array}{l}\text { Izrezati obrtna postolja, a zatim osovinske } \\
\text { sklopove iz obrtnih postolja. }\end{array}$ & \\
\hline 2. & $\begin{array}{c}\text { Sve očistiti, pregledati, premeriti (uz } \\
\text { popunjavanje merne liste), popraviti i obojiti. }\end{array}$ & \\
\hline 3. & $\begin{array}{l}\text { Neispravne plastične umetke obrtne šolje } \\
\text { zameniti. }\end{array}$ & \\
\hline 4. & Pregledati uzemljenje i, po potrebi, zameniti. & \\
\hline B & Osovinski sklop & \multirow{6}{*}{14} \\
\hline 1. & Očistiti osovine i proveriti ultrazvukom. & \\
\hline 2. & Proveriti mere osovine. & \\
\hline 3. & Proveriti ispravnost položaja točka na osovini. & \\
\hline 4. & $\begin{array}{l}\text { Proveriti mere profila točka i, po potrebi, } \\
\text { izvršiti reprofilisanje. }\end{array}$ & \\
\hline 5. & Izvršiti merenje električnog otpora. & \\
\hline $\mathbf{C}$ & Osovinska ležišta & \multirow[b]{2}{*}{18} \\
\hline 1. & $\begin{array}{c}\text { Skinuti kućišta ležišta, očistiti ih od stare } \\
\text { masti, pregledati ispravnost ležišta, zaptivnih } \\
\text { prstenova, lavirintskih prstenova, podmazati i } \\
\text { montirati. }\end{array}$ & \\
\hline D & Ogibljenje & \\
\hline 1. & $\begin{array}{l}\text { Skinuti lisnate opruge i proveriti ispravnost } \\
\text { listova, njihovog položaja, opasača i čepa na } \\
\text { njemu, ušica glavnih listova gibnjeva. Po } \\
\text { potrebi, popraviti ili ugraditi nove delove. }\end{array}$ & \multirow{3}{*}{2} \\
\hline 2. & $\begin{array}{l}\text { Montirati opruge } \mathrm{i} \text { ispitati ih na statičko } \\
\text { opterećenje uz popunjavanje merne liste. }\end{array}$ & \\
\hline 3. & $\begin{array}{l}\text { Proveriti mere vešajnih karika i, po potrebi, } \\
\text { ugraditi nove. }\end{array}$ & \\
\hline $\mathbf{E}$ & Kočnice & \multirow{11}{*}{42} \\
\hline 1. & Rastaviti kočnicu. & \\
\hline 2. & Proveriti ispravnost i mere bočnog polužja. & \\
\hline 3. & $\begin{array}{l}\text { Rasporednik zameniti ispravnim sa plombom } \\
\text { specijalizovane radionice. }\end{array}$ & \\
\hline 4. & $\begin{array}{l}\text { Kočni cilindar i kočno polužje popraviti u } \\
\text { specijalizovanim radionicama. }\end{array}$ & \\
\hline 5. & Podmazati sve taruće delove. & \\
\hline 6. & $\begin{array}{l}\text { Proveriti ispravnost vazdušnih vodova i } \\
\text { ispitati rezervoare za pritisak. }\end{array}$ & \\
\hline 7. & Kočne papuče zameniti. & \\
\hline 8. & Montirati kočnicu i izvršiti proveru rada. & \\
\hline 9. & $\begin{array}{l}\text { Izvršiti pregled uređaja ručne kočnice, } \\
\text { proveriti, popraviti i montirati. }\end{array}$ & \\
\hline 10 & $\begin{array}{l}\text { Razraditi vreteno ručne kočnice, podmazati } \\
\text { taruće delove i izvršiti proveru kočenja. }\end{array}$ & \\
\hline $\mathbf{F}$ & Tegljenički uređaj & \\
\hline 1. & $\begin{array}{l}\text { Rastaviti sve delove tegljenika i kvačila i } \\
\text { temeljito ih čistiti. }\end{array}$ & \\
\hline 2. & Proveriti mere i ispravnost tegljenika. & \\
\hline
\end{tabular}

\begin{tabular}{|c|c|c|}
\hline $\begin{array}{c}\text { Redni } \\
\text { broj }\end{array}$ & Naziv radova & $\begin{array}{l}\text { Potrebno } \\
\text { norma- } \\
\text {-časova }\end{array}$ \\
\hline 1. & 2 & 3. \\
\hline 3. & $\begin{array}{l}\text { Proveriti ispravnost pričvršćenja tegljenika na } \\
\text { postolje. }\end{array}$ & \multirow[t]{5}{*}{14} \\
\hline 4. & $\begin{array}{l}\text { Proveriti mere i ispravnost svornjaka ručice } \\
\text { vretena. }\end{array}$ & \\
\hline 5. & Proveriti ispravnost vretena i vešalice kvačila. & \\
\hline 6. & $\begin{array}{l}\text { Sastaviti tegljenike i kvačilo, podmazati i } \\
\text { razraditi. }\end{array}$ & \\
\hline 7. & Neispravne delove opraviti ili zameniti. & \\
\hline G & Odbojnici & \multirow{4}{*}{15} \\
\hline 1. & $\begin{array}{l}\text { Odbojnike skinuti, rastaviti i sve delove } \\
\text { temeljito očistiti. }\end{array}$ & \\
\hline 2. & $\begin{array}{l}\text { Proveriti karakteristike opruga, sastaviti } \\
\text { odbojnik i ispitati ga na statičko opterećenje. }\end{array}$ & \\
\hline 3. & Neispravne delove opraviti ili zameniti. & \\
\hline $\mathbf{H}$ & Postolje & \multirow{6}{*}{19} \\
\hline 1. & $\begin{array}{l}\text { Skinuti sve patosnice, pregledati, } \\
\text { neupotrebljive zameniti, upotrebljive i nove } \\
\text { impregnirati i postaviti izolacionu traku. }\end{array}$ & \\
\hline 2. & $\begin{array}{l}\text { Temeljito očistiti prljavštinu i koroziju sa } \\
\text { donjeg postolja. }\end{array}$ & \\
\hline 3. & $\begin{array}{l}\text { Proveriti ispravnost obrtnih šolja i centralnih } \\
\text { svornjeva. Popraviti ili zameniti. }\end{array}$ & \\
\hline 4. & $\begin{array}{l}\text { Proveriti ispravnost vođica kućišta ležišta na } \\
\text { njima i popraviti. }\end{array}$ & \\
\hline 5. & Obojiti postolje i sastavne delove. & \\
\hline $\mathbf{J}$ & $\begin{array}{c}\text { Antikoroziona zaštita (u zavisnosti od } \\
\text { oštećenja sistema zaštite) }\end{array}$ & \multirow{8}{*}{18} \\
\hline a) & $\begin{array}{l}\text { Delimična popravka boje sa završnim } \\
\text { premazom po celoj površini boka. }\end{array}$ & \\
\hline 1. & $\begin{array}{l}\text { Primeniti postupak pripreme površine na } \\
\text { oštećenim mestima četkama, brusonima ili } \\
\text { hemijskim sredstvima. }\end{array}$ & \\
\hline 2. & $\begin{array}{l}\text { Pripremiti postupak nanošenja sistema zaštite } \\
\text { na oštećena mesta, naneti završni premaz } \\
\text { raspršivanjem. }\end{array}$ & \\
\hline b) & Temeljno bojenje i zaštita & \\
\hline 1. & $\begin{array}{l}\text { Skinuti celokupni stari premaz i koroziju } \\
\text { mehaničkim ili hemijskim postupkom. }\end{array}$ & \\
\hline 2. & $\begin{array}{l}\text { Pripremiti površinu prema objavama UIC } \\
842-3 ; 842-4 \text {. }\end{array}$ & \\
\hline 3. & Naneti sistem zaštite prema UIC 824-4. & \\
\hline $\mathbf{K}$ & $\begin{array}{c}\text { Ispisivanje natpisa i oznaka } \\
\text { Po završenoj zaštiti i bojenju ispisati natpise i } \\
\text { oznake prema JŽS TO.003 i UIC842-4 }\end{array}$ & 9 \\
\hline $\mathbf{L}$ & Završni radovi & \multirow[b]{2}{*}{11} \\
\hline 1. & $\begin{array}{l}\text { Izvršiti završni pregled, merenje, } \\
\text { primopredaju kola i izraditi tehničku } \\
\text { dokumentaciju (merne liste). }\end{array}$ & \\
\hline & Ukupno: & $200 \mathrm{Nh}$ \\
\hline
\end{tabular}




\section{Zaključak}

U radu su sagledani osnovni parametri kvaliteta usluge u teretnom železničkom saobraćaju i transportu sa osvrtom na uslugu prevoza specijalnih tereta.

Upravljanje kvalitetom železničke usluge posmatrano je kao kompleksan proces koji je, pre svega, usmeren na ispunjavanje zahteva kvaliteta. U okviru toga predviđene su određene mere poboljšanja kvaliteta, a time i povećanja efektivnosti i efikasnosti pružanja usluge.

Dijagram toka samo je jedna od metoda i tehnika unapređenja kvaliteta železničke usluge. Ona pruža mogućnost grafičkog prikazivanja procesa planiranja i organizovanja prevoženja predimenzionisanih tereta i opasnih materija železnicom. Time se stvara osnova za unapređenje samog procesa, a ujedno se koristi kao sažeto radno uputstvo za izvršenje procesa planiranja i organizovanja prevoženja železnicom.

Transportovanje OM, koje su danas sve prisutnije, nosi niz opasnosti po životnu sredinu, a najefikasnija zaštita je preduzimanje adekvatnih preventivnih mera. Železnicom se prevoze vrlo respektabilne količine raznovrsnih opasnih materija. Železničkim kolima sa specifičnim sudovima - cisternama najviše se prevoze tečne, gasovite, zrnaste i praškaste opasne materije. Radi smanjenja delovanja štetnih posledica primenjuju se raznovrsne mere, korišćenjem rezultata brojnih istraživanja u Evropi i svetu. Pri tome se koriste i razvijaju odgovarajući standardi usaglašeni sa međunarodnim.

Železnička kola - cisterne, posmatrana kao sudovi za prevoz sa svojom pripadajućom specifičnom opremom, pored opštih konstrukcionih zahteva, moraju da poseduju brojne konstrukcione karakteristike uslovljene određenim fizičko-hemijskim osobinama opasnih materija.

Plato kola serije S, uvršćena u vozni park železnice, imaju posebno mesto u sistemu saobraćajne podrške snaga odbrane, jer se jedino njima prevoze teški predimenzionisani tereti, kao što su raznovrsna borbena vozila (guseničari i točkaši), inžinjerijske mašine i drugi borbeni sistemi.

Broj plato-kola u voznom parku železnice vrlo je ograničen, što može izazvati poteškoće u određenim uslovima kada se pojavi potreba za istovremenim angažovanjem njihovog većeg broja.

S obzirom na povećani stepen imobilizacije kola treba preduzeti potrebne mere na polju njihove eksploatacije i održavanja, kako bi se povećao broj ispravnih plato-kola. Adekvatne mere podrazumevaju poštovanje propisanih procedura i postupaka kao i vremenskih resursa pri održavanju.

Literatura:

[1] Pravilnik o međunarodnom i unutrašnjem železničkom prevozu opasnih stvari (RID), Zavod za NIP delatnost JŽ, Beograd, 2003.

[2] ISO 14001:1996, Environmental management systems Specification with guidance for use, 1996.

[3] ISO 14004:1996, Environmental management systems General guideline on principles, systems and supporting techniques, 1996.

[4] Jovanović, D.: Mogućnost unapređenja kvaliteta železničke transportne usluge, 6. međunarodna konferencija upravljanje kvalitetom i pouzdanošću DQM-2003, Beograd, 2003.

[5] Jovanović, D.: Upravljanje kvalitetom usluge u železničkom saobraćaju i transportu, XI naučno-stručna konferencija ŽELKON-04, Niš, 2004.

[6] Jovanović, D.: Mogućnost unapređenja kvaliteta prevoza opasnih materija železnicom, 7. međunarodna konferencija upravljanje kvalitetom i pouzdanošću DQM-2004, Beograd, 2004.

[7] Perišić, R.: Sistem kvaliteta usluga - logistika i informatika, Beograd, 2002.

[8] Eror, S.: Upravljanje železničkim saobraćajem, Zavod za NIP delatnost JŽ, Beograd,1988.

[9] Jugoslovenski standard, Sistem menadžmenta kvalitetom zahtevi, ISO 9000, 9001, Savezni zavod za standardizaciju, Beograd, 2001. 
Tehničke karakteristike plato-kola serije Smmps-tz (472)

Tabela 1 


\begin{tabular}{|c|c|c|c|c|}
\hline $\begin{array}{l}\text { Redni } \\
\text { broj }\end{array}$ & \multicolumn{2}{|l|}{ Naziv } & $\begin{array}{l}\text { Jed. } \\
\text { mere }\end{array}$ & Količina \\
\hline 1. & \multicolumn{2}{|l|}{ Broj osovina } & kom. & 4 \\
\hline 2. & \multicolumn{2}{|c|}{ Razmak stožera obrtnih postolja } & $\mathrm{m}$ & 7,20 \\
\hline 3. & \multicolumn{2}{|c|}{ Razmak krajnjih osovina } & $\mathrm{m}$ & 9,00 \\
\hline 4. & \multicolumn{2}{|c|}{ Dužina preko odbojnika } & $\mathrm{m}$ & 12,24 \\
\hline 5. & \multicolumn{2}{|c|}{ Korisna dužina poda } & $\mathrm{m}$ & 10,80 \\
\hline 6. & \multicolumn{2}{|c|}{ Korisna širina poda } & $\mathrm{m}$ & 3,15 \\
\hline 7. & \multicolumn{2}{|c|}{ Korisna površina poda } & $\mathrm{m}^{2}$ & 34.00 \\
\hline 8. & \multicolumn{2}{|c|}{ Sopstvena masa } & $\mathrm{t}$ & $20,3021,10$ \\
\hline \multirow{7}{*}{9.} & \multicolumn{2}{|c|}{ Granica tovarenja } & & \\
\hline & - obični & A & $\mathrm{t}$ & 38,00 \\
\hline & \multirow{2}{*}{ teretni režim } & B & $\mathrm{t}$ & 40,50 \\
\hline & & $\mathrm{C}$ & $\mathrm{t}$ & 59,50 \\
\hline & \multirow{2}{*}{ - režim "S" } & A & $\mathrm{t}$ & 38,00 \\
\hline & & $\mathrm{BC}$ & $\mathrm{t}$ & 40,50 \\
\hline & \multicolumn{2}{|c|}{ - režim "S S" ABC } & $\mathrm{t}$ & - \\
\hline 10. & \multicolumn{2}{|c|}{ Režim razmene } & & $\mathrm{NE}$ \\
\hline
\end{tabular}

Opis radova kod VO plato-kola serije Smmps-tz

Tabela 2

\begin{tabular}{|c|c|c|}
\hline $\begin{array}{r}\text { Redni } \\
\text { broj }\end{array}$ & Naziv radova & $\begin{array}{c}\text { Potrebno } \\
\text { norma- } \\
\text {-časova }\end{array}$ \\
\hline 1. & 2 & 3. \\
\hline $\mathbf{A}$ & Donji postroj i obrtno postolje & \multirow{5}{*}{38} \\
\hline 1. & $\begin{array}{l}\text { Izrezati obrtna postolja, a zatim osovinske } \\
\text { sklopove iz obrtnih postolja. }\end{array}$ & \\
\hline 2. & $\begin{array}{c}\text { Sve očistiti, pregledati, premeriti (uz } \\
\text { popunjavanje merne liste), popraviti i obojiti. }\end{array}$ & \\
\hline 3. & $\begin{array}{c}\text { Neispravne plastične umetke obrtne šolje } \\
\text { zameniti. }\end{array}$ & \\
\hline 4. & Pregledati uzemljenje i, po potrebi, zameniti. & \\
\hline B & Osovinski sklop & \multirow{6}{*}{14} \\
\hline 1. & Očistiti osovine i proveriti ultrazvukom. & \\
\hline 2. & Proveriti mere osovine. & \\
\hline 3. & Proveriti ispravnost položaja točka na osovini. & \\
\hline 4. & $\begin{array}{l}\text { Proveriti mere profila točka i, po potrebi, } \\
\text { izvršiti reprofilisanje. }\end{array}$ & \\
\hline 5. & Izvršiti merenje električnog otpora. & \\
\hline $\mathbf{C}$ & Osovinska ležišta & \multirow[b]{2}{*}{18} \\
\hline 1. & $\begin{array}{c}\text { Skinuti kućišta ležišta, očistiti ih od stare } \\
\text { masti, pregledati ispravnost ležišta, zaptivnih } \\
\text { prstenova, lavirintskih prstenova, podmazati i } \\
\text { montirati. }\end{array}$ & \\
\hline D & Ogibljenje & \\
\hline
\end{tabular}




\begin{tabular}{|c|c|c|}
\hline $\begin{array}{c}\text { Redni } \\
\text { broj }\end{array}$ & Naziv radova & $\begin{array}{c}\text { Potrebno } \\
\text { norma- } \\
\text {-časova }\end{array}$ \\
\hline 1. & 2 & 3. \\
\hline 1. & $\begin{array}{l}\text { Skinuti lisnate opruge i proveriti ispravnost } \\
\text { listova, njihovog položaja, opasača i čepa na } \\
\text { njemu, ušica glavnih listova gibnjeva. Po } \\
\text { potrebi, popraviti ili ugraditi nove delove. }\end{array}$ & \multirow{3}{*}{2} \\
\hline 2. & $\begin{array}{l}\text { Montirati opruge } \mathrm{i} \text { ispitati ih na statičko } \\
\text { opterećenje uz popunjavanje merne liste. }\end{array}$ & \\
\hline 3. & $\begin{array}{l}\text { Proveriti mere vešajnih karika i, po potrebi, } \\
\text { ugraditi nove. }\end{array}$ & \\
\hline $\mathbf{E}$ & Kočnice & \multirow{3}{*}{42} \\
\hline 1. & Rastaviti kočnicu. & \\
\hline 2. & Proveriti ispravnost i mere bočnog polužja. & \\
\hline 3. & $\begin{array}{l}\text { Rasporednik zameniti ispravnim sa plombom } \\
\text { specijalizovane radionice. }\end{array}$ & \\
\hline 4. & $\begin{array}{l}\text { Kočni cilindar i kočno polužje popraviti u } \\
\text { specijalizovanim radionicama. }\end{array}$ & \\
\hline 5. & Podmazati sve taruće delove. & \\
\hline 6. & $\begin{array}{l}\text { Proveriti ispravnost vazdušnih vodova i } \\
\text { ispitati rezervoare za pritisak. }\end{array}$ & \\
\hline 7. & Kočne papuče zameniti. & \\
\hline 8. & Montirati kočnicu i izvršiti proveru rada. & \\
\hline 9. & $\begin{array}{l}\text { Izvršiti pregled uređaja ručne kočnice, } \\
\text { proveriti, popraviti i montirati. }\end{array}$ & \\
\hline 10. & $\begin{array}{l}\text { Razraditi vreteno ručne kočnice, podmazati } \\
\text { taruće delove i izvršiti proveru kočenja. }\end{array}$ & \\
\hline $\mathbf{F}$ & Tegljenički uredaj & \multirow{8}{*}{14} \\
\hline 1. & $\begin{array}{l}\text { Rastaviti sve delove tegljenika i kvačila i } \\
\text { temeljito ih čistiti. }\end{array}$ & \\
\hline 2. & Proveriti mere i ispravnost tegljenika. & \\
\hline 3. & $\begin{array}{l}\text { Proveriti ispravnost pričvršćenja tegljenika na } \\
\text { postolje. }\end{array}$ & \\
\hline 4. & $\begin{array}{l}\text { Proveriti mere i ispravnost svornjaka ručice } \\
\text { vretena. }\end{array}$ & \\
\hline 5. & Proveriti ispravnost vretena i vešalice kvačila. & \\
\hline 6. & $\begin{array}{l}\text { Sastaviti tegljenike i kvačilo, podmazati i } \\
\text { razraditi. }\end{array}$ & \\
\hline 7. & Neispravne delove opraviti ili zameniti. & \\
\hline G & Odbojnici & \multirow{4}{*}{15} \\
\hline 1. & $\begin{array}{l}\text { Odbojnike skinuti, rastaviti i sve delove } \\
\text { temeljito očistiti. }\end{array}$ & \\
\hline 2. & $\begin{array}{l}\text { Proveriti karakteristike opruga, sastaviti } \\
\text { odbojnik i ispitati ga na statičko opterećenje. }\end{array}$ & \\
\hline 3. & Neispravne delove opraviti ili zameniti. & \\
\hline $\mathbf{H}$ & Postolje & \multirow{6}{*}{19} \\
\hline 1. & $\begin{array}{l}\text { Skinuti sve patosnice, pregledati, } \\
\text { neupotrebljive zameniti, upotrebljive i nove } \\
\text { impregnirati i postaviti izolacionu traku. }\end{array}$ & \\
\hline 2. & $\begin{array}{l}\text { Temeljito očistiti prljavštinu i koroziju sa } \\
\text { donjeg postolja. }\end{array}$ & \\
\hline 3. & $\begin{array}{l}\text { Proveriti ispravnost obrtnih šolja i centralnih } \\
\text { svornjeva. Popraviti ili zameniti. }\end{array}$ & \\
\hline 4. & $\begin{array}{l}\text { Proveriti ispravnost vođica kućišta ležišta na } \\
\text { njima i popraviti. }\end{array}$ & \\
\hline 5. & Obojiti postolje i sastavne delove. & \\
\hline
\end{tabular}




\begin{tabular}{|c|c|c|}
\hline $\begin{array}{c}\text { Redni } \\
\text { broj }\end{array}$ & Naziv radova & $\begin{array}{c}\text { Potrebno } \\
\text { norma- } \\
\text {-časova }\end{array}$ \\
\hline 1. & 2 & 3. \\
\hline $\mathbf{J}$ & $\begin{array}{c}\text { Antikoroziona zaštita (u zavisnosti od } \\
\text { oštećenja sistema zaštite) }\end{array}$ & \multirow{8}{*}{18} \\
\hline a) & $\begin{array}{l}\text { Delimična popravka boje sa završnim } \\
\text { premazom po celoj površini boka. }\end{array}$ & \\
\hline 1. & $\begin{array}{l}\text { Primeniti postupak pripreme površine na } \\
\text { oštećenim mestima četkama, brusevima ili } \\
\text { hemijskim sredstvima. }\end{array}$ & \\
\hline 2. & $\begin{array}{l}\text { Pripremiti postupak nanošenja sistema zaštite } \\
\text { na oštećena mesta, naneti završni premaz } \\
\text { raspršivanjem. }\end{array}$ & \\
\hline b) & Temeljno bojenje i zaštita & \\
\hline 1. & $\begin{array}{l}\text { Skinuti celokupni stari premaz i koroziju } \\
\text { mehaničkim ili hemijskim postupkom. }\end{array}$ & \\
\hline 2. & $\begin{array}{l}\text { Pripremiti površinu prema objavama UIC } \\
842-3 ; 842-4 \text {. }\end{array}$ & \\
\hline 3. & Naneti sistem zaštite prema UIC 824-4. & \\
\hline $\mathbf{K}$ & $\begin{array}{c}\text { Ispisivanje natpisa i oznaka. } \\
\text { Po završenoj zaštiti i bojenju ispisati natpise i } \\
\text { oznake prema JŽS TO.003 i UIC842-4 }\end{array}$ & 9 \\
\hline $\mathbf{L}$ & Završni radovi & \multirow[b]{2}{*}{11} \\
\hline \multirow[t]{2}{*}{1.} & $\begin{array}{l}\text { Izvršiti završni pregled, merenje, } \\
\text { primopredaju kola i izraditi tehničku } \\
\text { dokumentaciju (merne liste). }\end{array}$ & \\
\hline & Ukupno: & $200 \mathrm{Nh}$ \\
\hline
\end{tabular}

$\Lambda$

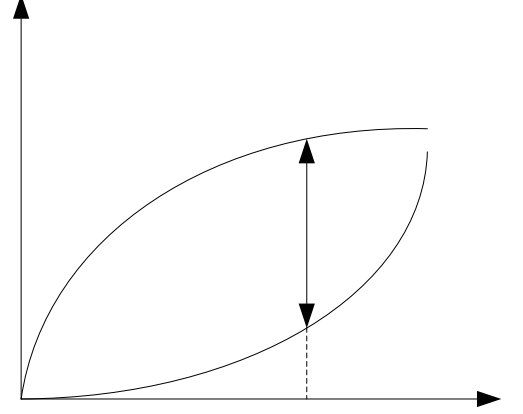

Sl. - 1 Odnos cene i kvaliteta usluge 


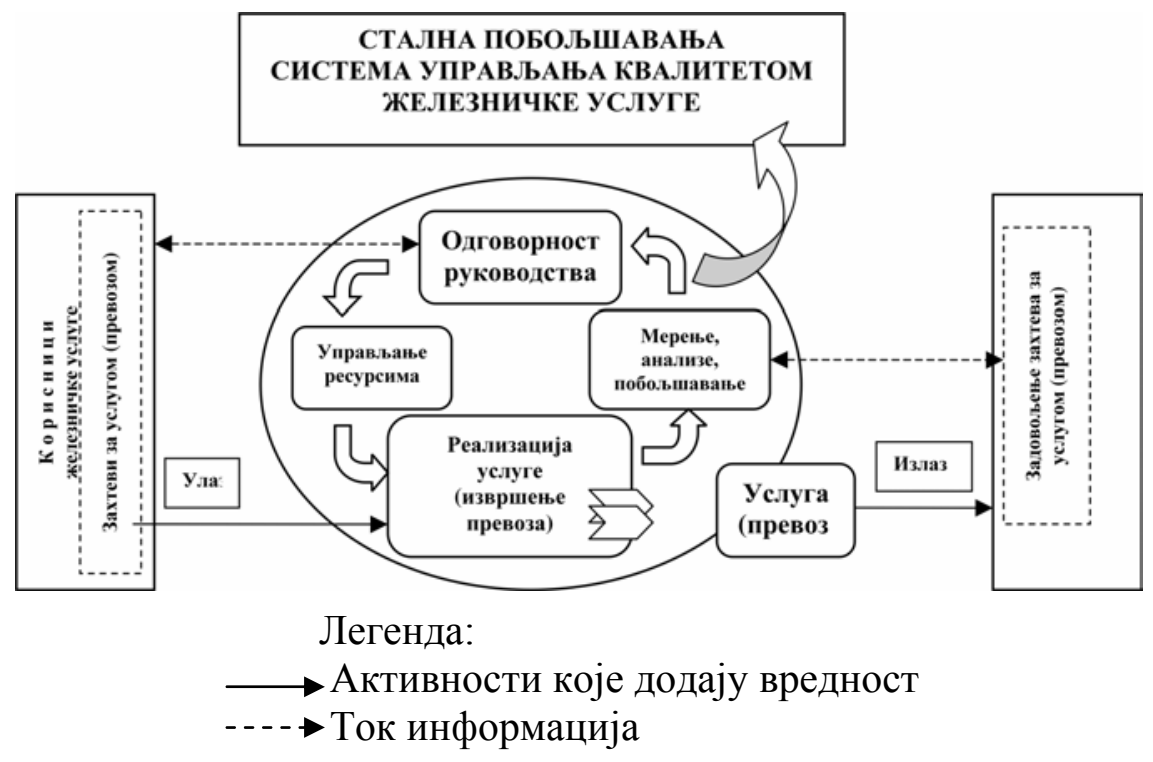

Sl. 2 - Model sistema upravljanja kvalitetom železničke usluge zasnovanog na procesima 


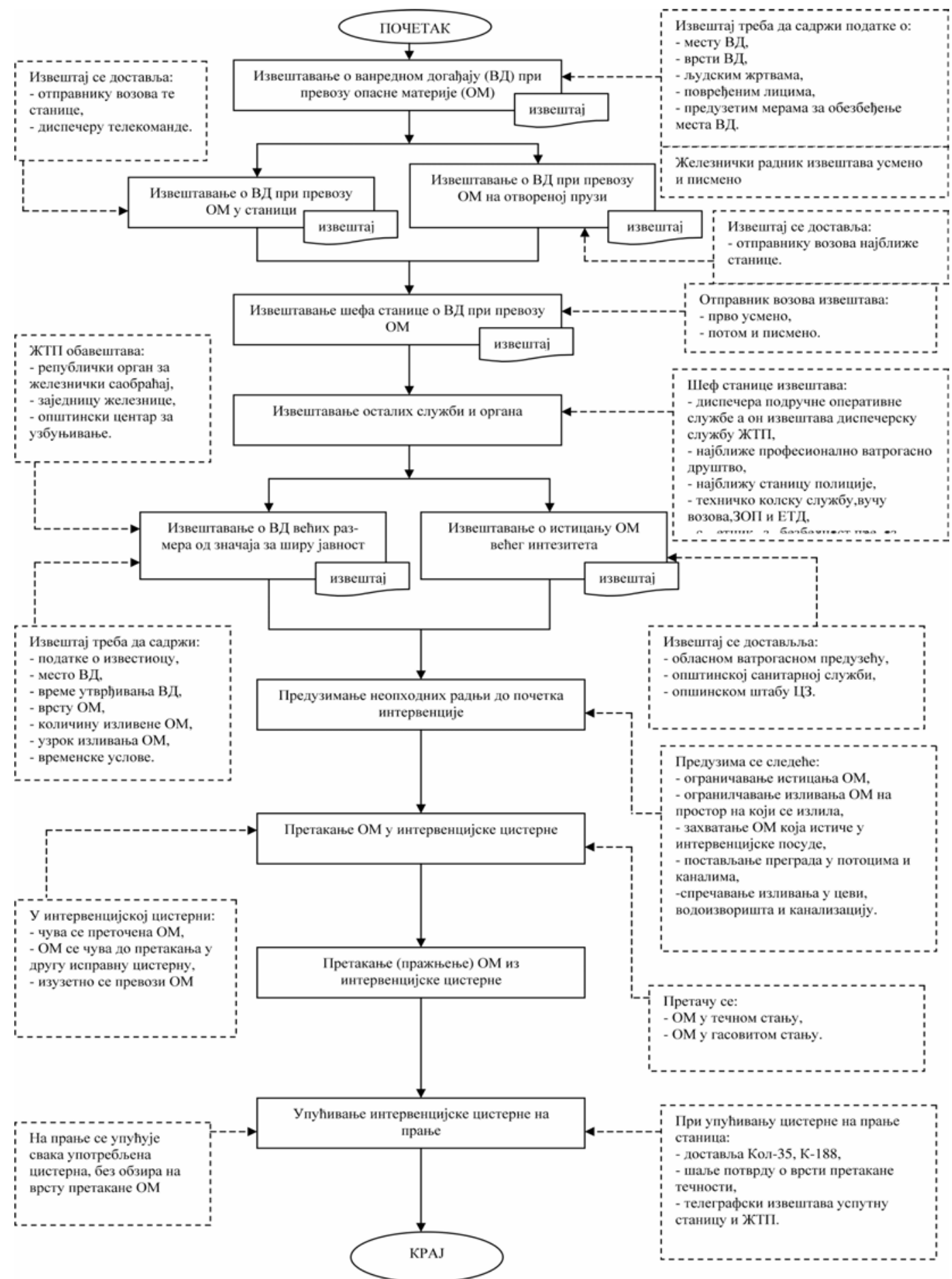

Sl. 3 - Dijagram toka postupaka izveštavanja i intervenisanja pri vanrednom događaju nastalom pri prevozu opasnih materija železnicom 


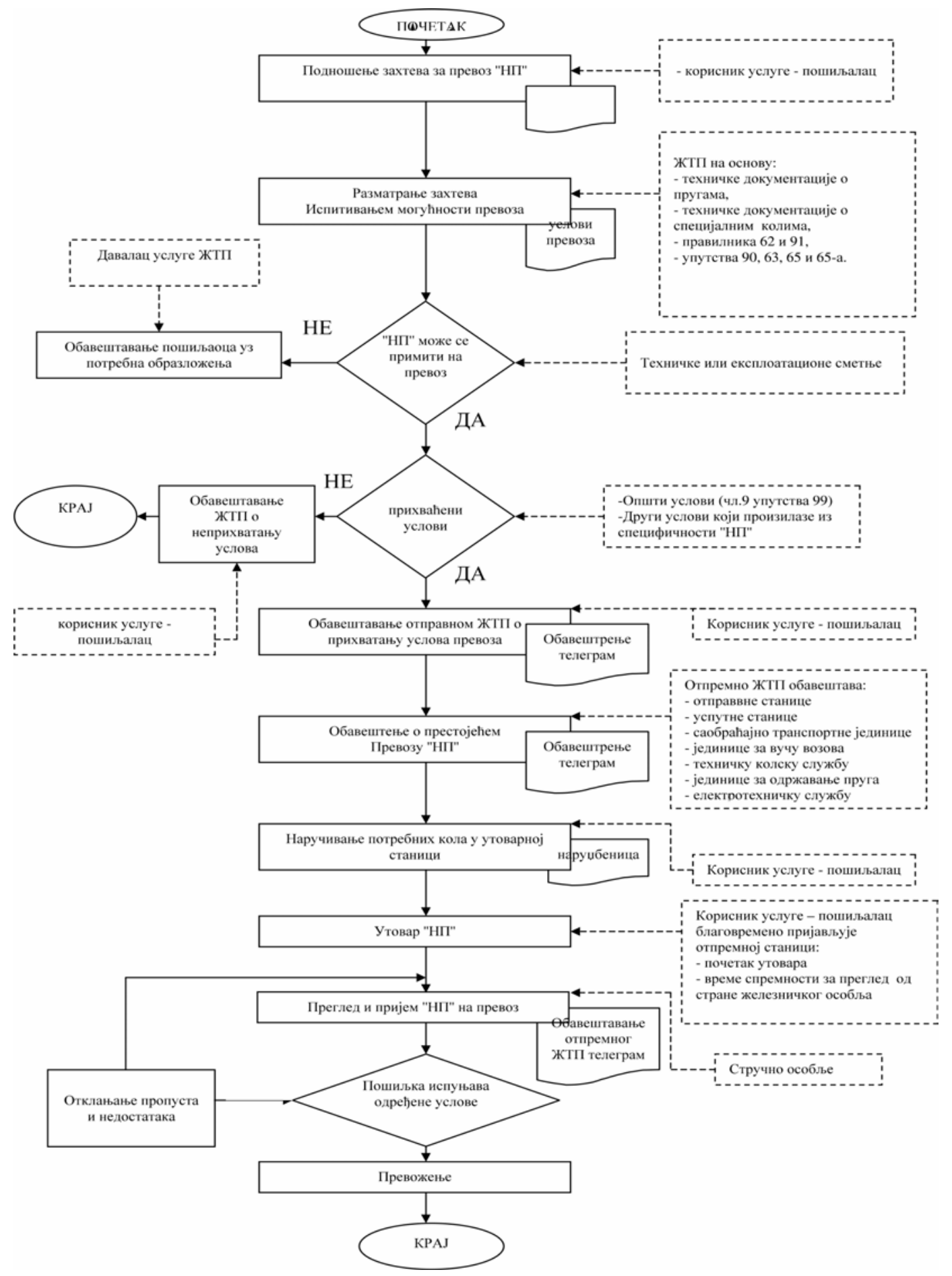

Sl. 4 - Dijagram toka postupaka organizovanja prevoza naročitih pošiljaka železnicom 


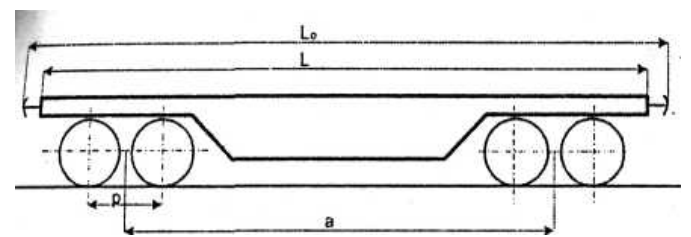

Sl. 5 - Šematski prikaz plato-kola serije Smmps-tz (472) 